\title{
$\begin{array}{llllllllllllllll}\text { A } & \text { C } & \text { T } & \text { A } & \text { T } & \text { H } & \text { E } & \text { R } & \text { I } & \text { O } & \text { L } & \text { O } & \text { G } & \text { I } & \text { C } & \text { A }\end{array}$ \\ VOL. XVI, 21: $341-357$. \\ BIAŁOWIEŻA \\ November, 1971
}

Andrzej L. R U P R E C H T

\section{Taxonomic Value of Mandible Measurements in Soricidae (Insectivora)}

[With 4 Tables \& 5 Figs.]

\begin{abstract}
Studies were made of variations in dimensions of the rostral part of the skull in 9 species of Soricidae of the genera Sorex, Neomys and Crocidura, originating from Central and West Europe $(n=3124)$. The postglenoid breadth is a useful taxonomic character for distinguishing three lowland shrews of the genus Sorex and is of supplementary significance in identification of skulls of the genera Neomys and Crocidura. Mandible length and height of ramus mandibulae are good diagnostic characters. The two mandible measurements set out on a diagram of their correlations make it possible almost completely to identify the majority of the species. Sorex alpinus is almost completely distinguishable from $S$. araneus on the basis of the mandibular index (mandible length: height of ramus mandibulae). These methods can be applied practically in identification of fossil material or material originating from owl pellets under the conditions of Central Europe.
\end{abstract}

\section{INTRODUCTION}

In view of the increasing popularity of using owl pellets, for studying the composition of the food of these birds, and in zoogeography, the need has arisen for the elaboration of methods facilitating indentification of different species (including Soricidae). As the material may be damaged to some extent it is essential to base findings on the best preserved elements.

In practice use has been made up to the present of both descriptive characters (R a c zyński, 1961; Richter, 1964) and also of suitably chosen measurements of the rostral part of the skull (B u c halc z y k \& R a c zyński, 1961; Richter, 1963; B ühler, 1964; H a mar \& Simionescu, 1967; Schmidt, 1967 and 1969; and Rempe \& B ühler, 1969).

It consequently appeared desirable to assess the practical usefulness of two measurements of the mandible applied simultaneously in the form of a correlation table (cf. R u precht, 1969) for distinguishing different 
species of the genera Sorex, Neomys and Crocidura, in pairs differing little in respect of dimensions.

In addition a check was made of the usefulness of earlier data given by B u chalczyk \& Raczyński (1961) on suitably numerous comparative material from different regions of Poland and Europe.

\section{MATERIALS AND METHODS}

Approximately 3124 specimens of Soricidae, belonging to 9 species, and originating from Poland, Czechoslovakia, Austria, Germany and Belgium, were used for these studies. The usefulness of mandible measurements was analyzed in the following pairs of species; $S$. alpinus $-S$. araneus, $S$. caecutiens $-S$. minutus, $S$. caecutiens - S. araneus, $N$. fodiens $-N$. anomalus, C. leucodon - C. russula, and also C. leucodon - C. suaveolens. Material from collections in the Mammals Research Institute of the Polish Academy od Sciences at Białowieża, Národni Muzeum in Prague, Zoological Museum of the Humboldt University, Berlin, Department of Zoology of the Agricultural College, Wrocław, and also the measurements of $N$. fodiens and N. anomalus from Fulda in Germany and Neusiedler See in Austria, which Dr. H. $\mathrm{P}$ i e per made available, were used for the above purpose.

Measurements were made of the rostral part of the skull with accuracy to $0.1 \mathrm{~mm}$, as follows: (1) postglenoid breadth, (2) height of ramus mandibulae - the two first measurements after B uchalczy k \& R a c zyński (1961) and (3) mandible length measured from the pericentral margin of alveolus $\mathrm{I}_{1}$ to the end of proc. articularis mandibulae (after B ü hl e r, 1964).

In the case of a pair of species of similar dimensions (S. alpinus - S. araneus, calculation was made of the mandibular index - mandible length : height of ramus mandibulae).

Significance of differences between average values was checked as necessary by the $t$-Student test for comparison of averages of independent groups.

\section{RESULTS}

3. 1. S. alpinus - S. araneus

These species cannot be distinguished on the basis of absolute values of three measurements of the skull, as the ranges of their variations overlap to a great extent (Table 1).

It is, however, possible almost completely to separate the two species by means of the mandibular index (mandible length: height of ramus mandibulae) - (Fig. 1, Table 2).

This fact is due to the different proportions in the structure of the mandible in these shrews. $S$. alpinus is distinguished by an elongated mandible (avg. $=9.98 \mathrm{~mm}$ ), with relatively low muscular process (proc. coronoideus - avg. $=4.00 \mathrm{~mm}$ ) in relation to the more shortened (avg. $=9.62$ $\mathrm{mm}$ ) mandible, possessing a higher muscular process (avg. $=4.53 \mathrm{~mm}$ ), in S. araneus. 


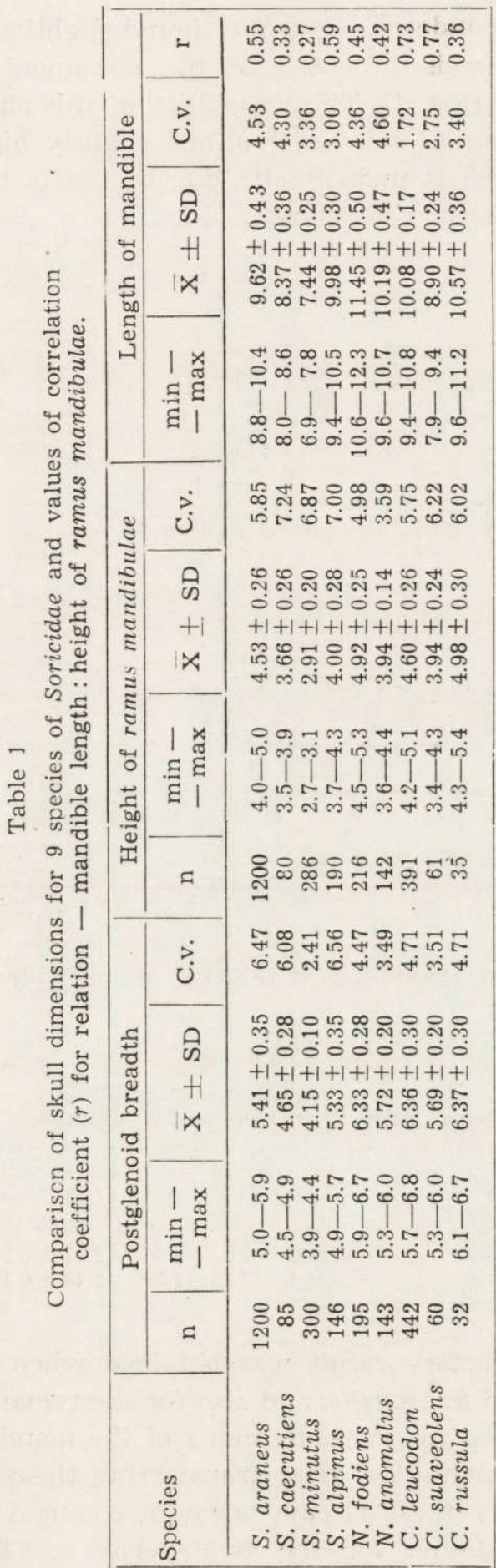


The values of this index were in fact found slightly to overlap in class 2.36 , which corresponds to $0.08 \%$ of the specimens of $S$. araneus and $1.05 \%$ of $S$. alpinus (Fig. 1). The variability of this character is slight in the case of $S$. alpinus (C. $v .=5.64 \%$ ), and slightly higher in $S$. araneus (C. $v .=9.48 \%$ ) which is undoubtedly due to the fact that the material came from different parts of Poland.

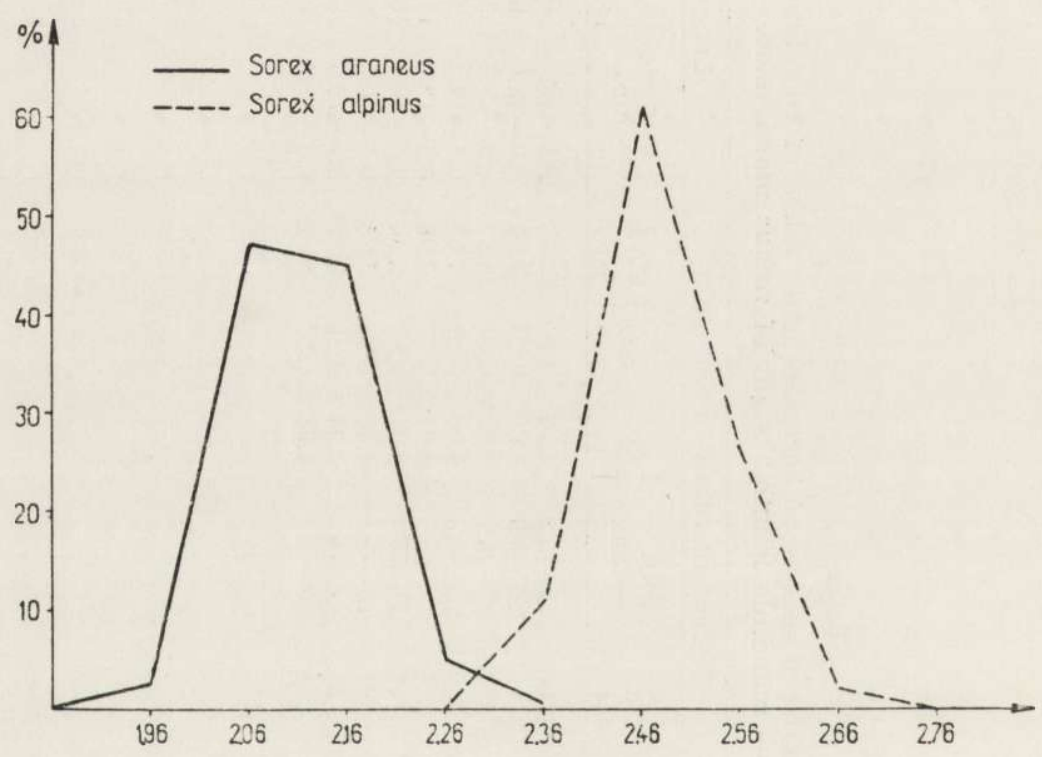

Fig. 1. Distribution in percentages of values of the mandibular index in Sorex.

Table 2

Ranges of variation in mandibular index for S. araneus and S. alpinus.

\begin{tabular}{|l|r|r|r|r|}
\hline \multicolumn{1}{|c|}{ Species } & $\mathrm{n}$ & $\min -\max$ & $\overline{\mathrm{x}} \pm \mathrm{SD}$ & C. v. \\
\hline Sorex arcneus & 1200 & $1.95-2.36$ & $2.11 \pm 0.20$ & 9.48 \\
Sorex alpinus & 190 & $2.36-2.70$ & $2.48 \pm 0.14$ & 5.64 \\
\hline
\end{tabular}

An equally satisfactory result was obtained when distinguishing between $S$. alpinus and $S$. araneus, and also for the remaining species of $S o-$ ricidae, by correlating two measurements of the mandible - length and height of ramus mandibulae, after transferring them to the correlation table (Fig. 2). Under these circumstances a common class of mandible measurements was found for the two species - 9.9/4.2 $\mathrm{mm}$, covering 
$0.08 \%$ of the specimens of $S$. araneus and $0.52 \%$ of $S$. alpinus. The variations in mandible measurements are not great in the two species, being slightly greater in the case of height of ramus mandibulae and postglenoid breadth (Table 1).

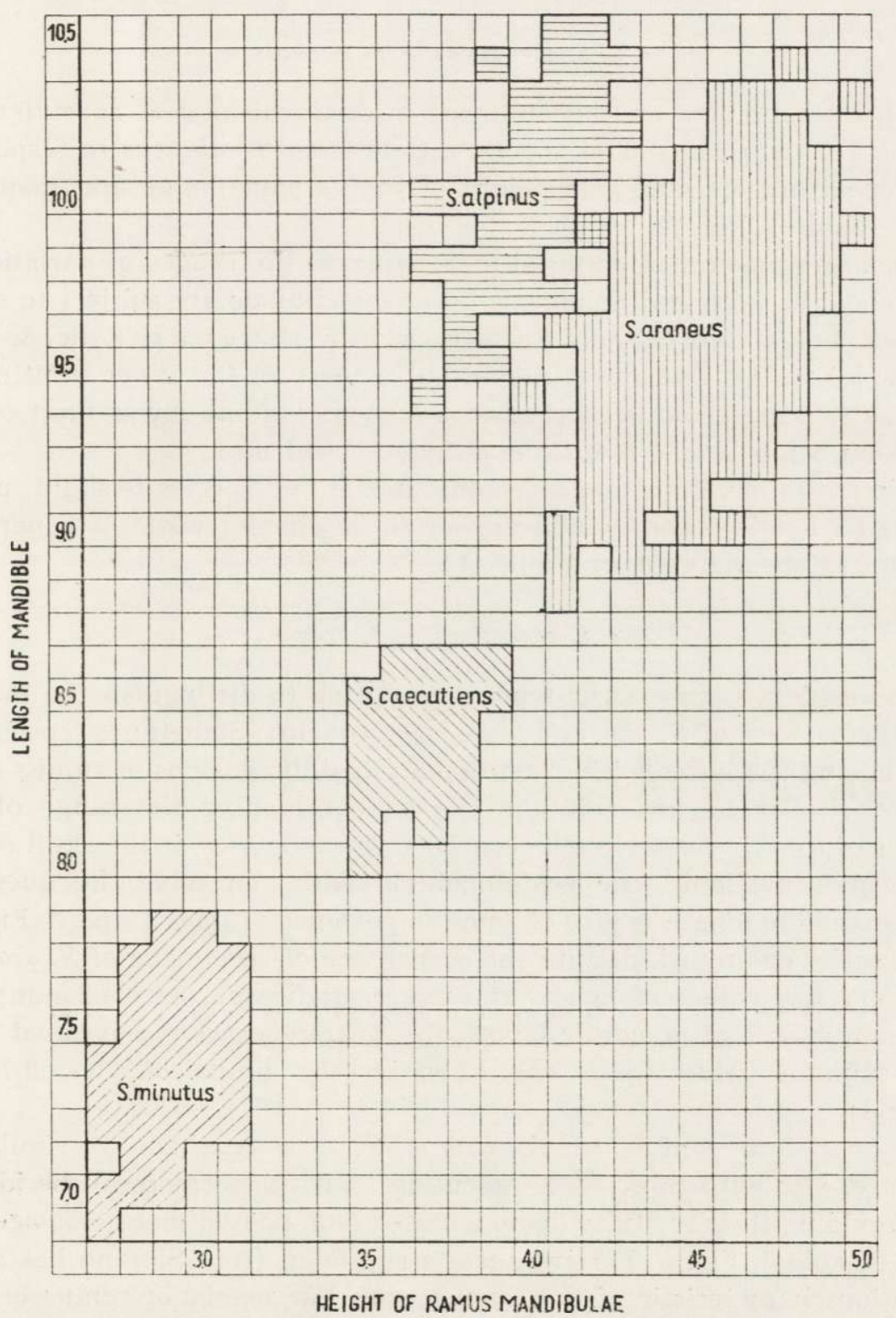

Fig. 2. Relation between mandible length and height of ramus mandibulae in representatives of the genus Sorex. 
In $S$. araneus the maximum values of postglenoid breadth are $0.2 \mathrm{~mm}$ greater, and minimum values of height of ramus mandibulae $0.3 \mathrm{~mm}$ less than the earlier data given by Buchalc zy k \& R a c z yn ski (1961). Thus the minimum values of ramus mandibulae approached the range of variations of this character characteristic of $S$. caecutiens.

$$
\text { 3. 2. S. caecutiens }-S \text {. minutus }
$$

No great difficulty was encountered in distinguishing $S$. caecutiens on the basis of the results. This species differs from $S$. minutus in respect of postglenoid breadth and also height of ramus mandibulae and mandible length (Table 1, Fig. 2).

In a larger amount of material of $S$. minutus the ranges of variation of postglenoid breadth and height of ramus mandibulae are subject to slight changes comparable to the data gathered by $\mathrm{Buchalczyk} \& \mathrm{Ra}$ c z y ńs k i (1961). The author found an increase in the lower limit of 0.1 $\mathrm{mm}$ of the postglenoid breadth, and a lowering of the lower limit of the minimum height of the ramus mandibulae by $0.1 \mathrm{~mm}$.

Variation in mandible measurements in the two species is slight, particularly its length which would appear to be characteristic in general of the dimension analyzed (cf. Table 1).

\section{3. S. caecutiens $-S$. araneus}

Some difficulty may occur when attempting to distinguish the mandibles themselves of $S$. caecutiens and $S$. araneus. Sometimes specimens occur among the latter with exceptionally low dimensions of ramus mandibulae, similar to, and frequently even overlapping the range of variations of this character in $S$. caecutiens. In such cases, if the skull of the specimen is available, the postglenoid breadth can solve the question, while mandible length is also of some importance (Tables 1 and 3, Fig. 2). In the series examined, despite the occurrence of specimens of $S$. araneus with very low values of height of ramus mandibulae $(3.9-4.2 \mathrm{~mm})$, the minimum values of mandible length for $S$. araneus were separated from the maximum values for $S$. caecutiens by the limits of class $8.7 \mathrm{~mm}$ (Table 1).

It is possible to confuse small skulls of $S$. araneus which are similar in respect of size with those of $S$. caecutiens, but the former can be identified providing they are fully documentated (e.g. body dimensions, age and sex) - Table 3, Fig. 3. For instance: a specimen from Sierżno has a Cb. dimension characteristic of $S$. araneus, with low height of ramus mandibulae. A 50-day old individual of $S$. araneus kept in captivity (Mamm. Res. Inst., coll. no. 91121), on the other hand, has Cb. characteristic of 


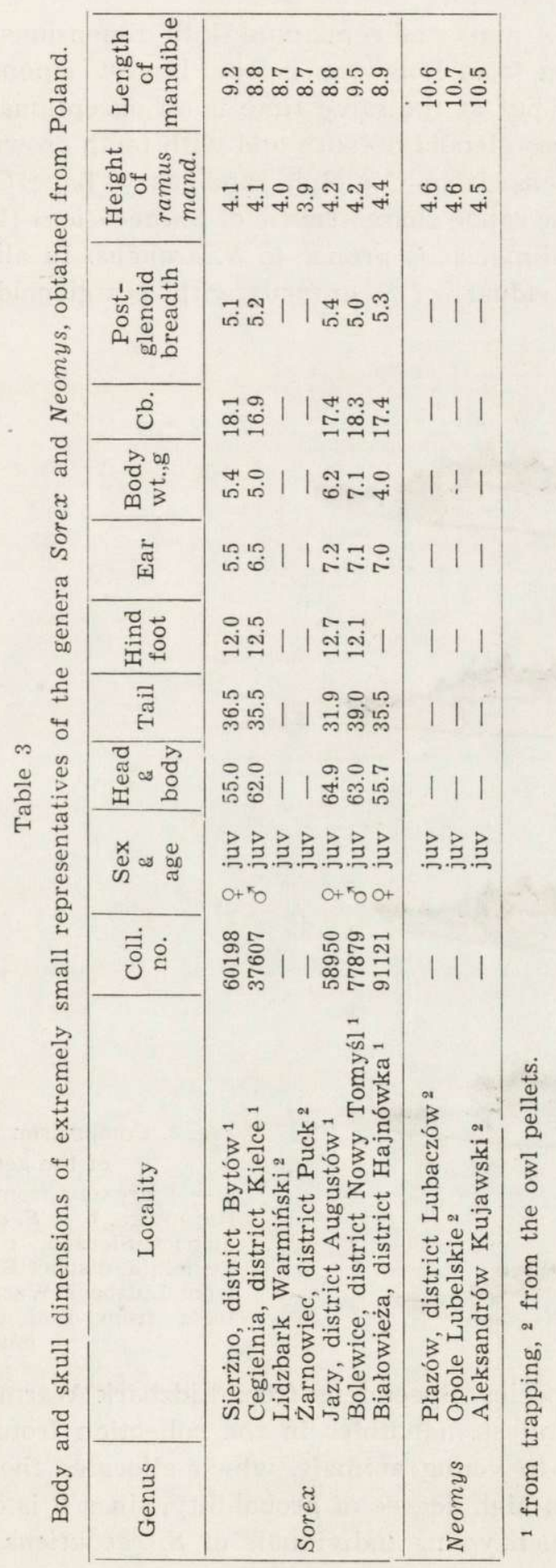


S. caecutiens $(17.4 \mathrm{~mm})$, and remaining skull dimensions proper to $S$. araneus. A specimen from Bolewice is the largest among the remainder $(\mathrm{Cb} .=18.3 \mathrm{~mm})$ but at the same time is an exceptionally young animal with minimum postglenoid breadth and with tooth crowns not completely erupted. Specimens from Cegielnia and Jazy have Cb. measurements coming within the range characteristic of $S$. caecutiens $(16.9$ and $17.4 \mathrm{~mm}$ ), but other skull dimensions proper to $S$. araneus. In all five cases these were young individuals of $S$. araneus with postglenoid breadth values

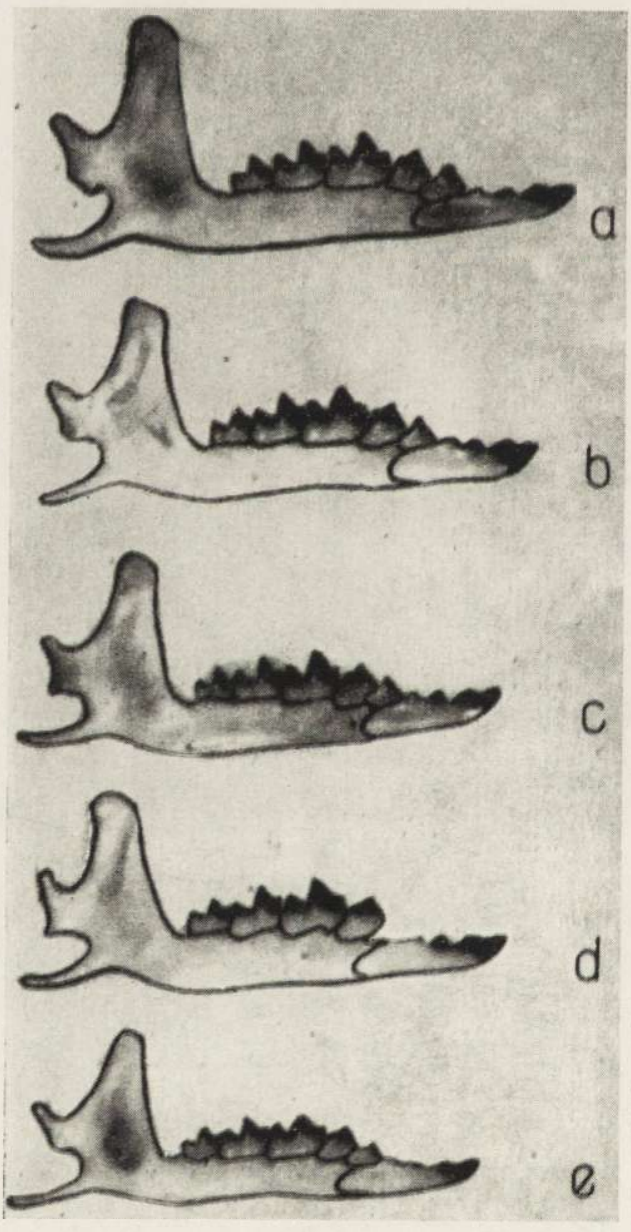

Fig. 3. Comparison of size of mandibles of the genus Sorex.

a - S. araneus from Białowieża, district Hajnówka, b - S. araneus' from Bytów, district Sierżno, c $-S$. araneus from Cegielnia, district Kielce, d-S. araneus from Lidzbark Warmiński, e $-S$. caecutiens from Białowieża, district Hajnówka.

typical of this species. Specimens from Lidzbark Warmiński and Żarnowiec are the smallest mandibles in the collection from Polish territory and also belong to young animals, which allocates them to the species $S$. araneus with a high degree of probability, since it is difficult to accept that there are such young individuals of $S$. caecutiens distinguished by 
relatively large, negligibly worn teeth and maximum mandible measurements.

To sum up the examples given it must be said that body measurements and $\mathrm{Cb}$. length of the skull cannot form an absolutely certain basis for allocating such »atypical" specimens to the species $S$. caecutiens. A correct diagnosis can only be made if a whole complex of characters is taken into consideration.

$$
\text { 3. 4. N. fodiens - N. anomalus }
$$

No great difficulty was encountered in distinguishing the two species of the genus Neomys, except in the case of three specimens (cf. Table 3). Mandible measurements were entered on the correlation table and then completely divided the two species, despite the fact that the values of their length dimensions partly overlapped each other (Fig. 4).

Postglenoid breadth exhibits a tendency in both species for the extreme values to overlap, nevertheless it can be of supplementary taxonomic value (Table 1).

$$
\text { Table } 4
$$

Variations in mandible dimensions of representatives of the genus Neomys

\begin{tabular}{|c|c|c|c|c|c|c|c|c|}
\hline \multirow{2}{*}{ 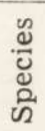 } & \multirow[b]{2}{*}{ Locum } & \multicolumn{4}{|c|}{ Height of ramus mandibulae } & \multicolumn{3}{|c|}{ Length of mandible } \\
\hline & & $\mathrm{n}$ & ${ }_{-\max }^{\min }$ & $\bar{x} \pm S D$ & C. v. & $\underset{-\max }{\min }$ & $\bar{x} \pm S D$ & C. $v$. \\
\hline $\begin{array}{l}\text { ड్ } \\
\text { ర్ } \\
\text { है } \\
\text { है } \\
z\end{array}$ & $\begin{array}{l}\text { Białowieża } \\
\text { Bieszczady Mts } \\
\text { Pomerania } \\
\text { Neusiedler See } \\
\text { Fulda }\end{array}$ & $\begin{array}{r}109 \\
17 \\
16 \\
75 \\
21\end{array}$ & $\begin{array}{l}3.6-4.2 \\
4.1-4.4 \\
3.8-4.2 \\
4.0-4.5 \\
3.9-4.2\end{array}$ & $\begin{array}{l}3.88 \pm 0.30 \\
4.20 \pm 0.22 \\
3.99 \pm 0.20 \\
4.24 \pm 0.11 \\
4.10 \pm 0.10\end{array}$ & $\begin{array}{l}7.73 \\
5.32 \\
5.01 \\
2.59 \\
2.44\end{array}$ & $\begin{array}{r}9.7-10.6 \\
10.1-10.7 \\
9.6-10.6 \\
9.6-10.8 \\
9.6-10.5\end{array}$ & $\begin{array}{l}10.17 \pm 0.49 \\
10.48 \pm 0.45 \\
10.01 \pm 0.32 \\
10.21 \pm 0.37 \\
10.04 \pm 0.41\end{array}$ & $\begin{array}{l}4.82 \\
4.27 \\
3.16 \\
3.62 \\
4.08\end{array}$ \\
\hline 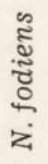 & $\begin{array}{l}\text { Białowieża } \\
\text { Bieszczady Mts } \\
\text { Pomerania } \\
\text { Neusiedler See } \\
\text { Fulda }\end{array}$ & $\begin{array}{r}101 \\
77 \\
38 \\
174 \\
171\end{array}$ & $\begin{array}{l}4.5-5.3 \\
4.6-5.3 \\
4.5-5.1 \\
4.5-5.3 \\
4.5-5.3\end{array}$ & $\begin{array}{l}4.92 \pm 0.20 \\
4.97 \pm 0.24 \\
4.82 \pm 0.28 \\
5.01 \pm 0.14 \\
4.92 \pm 0.20\end{array}$ & $\begin{array}{l}4.06 \\
4.93 \\
5.87 \\
2.79 \\
4.06\end{array}$ & $\begin{array}{l}10.9-12.3 \\
10.6-12.2 \\
10.7-11.7 \\
10.4-12.3 \\
10.4-12.2\end{array}$ & $\begin{array}{l}11.54 \pm 0.43 \\
11.49 \pm 0.48 \\
11.14 \pm 0.30 \\
11.42 \pm 0.30 \\
11.24 \pm 0.22\end{array}$ & $\begin{array}{l}3.77 \\
4.17 \\
2.69 \\
2.62 \\
1.96\end{array}$ \\
\hline
\end{tabular}
from five sympatric populations from Poland, Austria and Germany.

Variation in the three skull dimensions analyzed (C. $v .=3.49-4.98 \%$ ) in the two species of the genus Neomys is small, which justifies their being regarded as good taxonomic characters (Table 1).

Comparative materials for the two species of the genus Neomys were available from five populations originating from the zone of their sympatric range in East and West Europe. In both $N$. fodiens and $N$. anomalus from Poland, Germany and Austria a tendency was observed in some populations, particularly from West Europe, for one or both mandible dimensions to overlap each other (Table 4). In material from Poland a zone of mutual overlapping in respect of mandible length was observed 


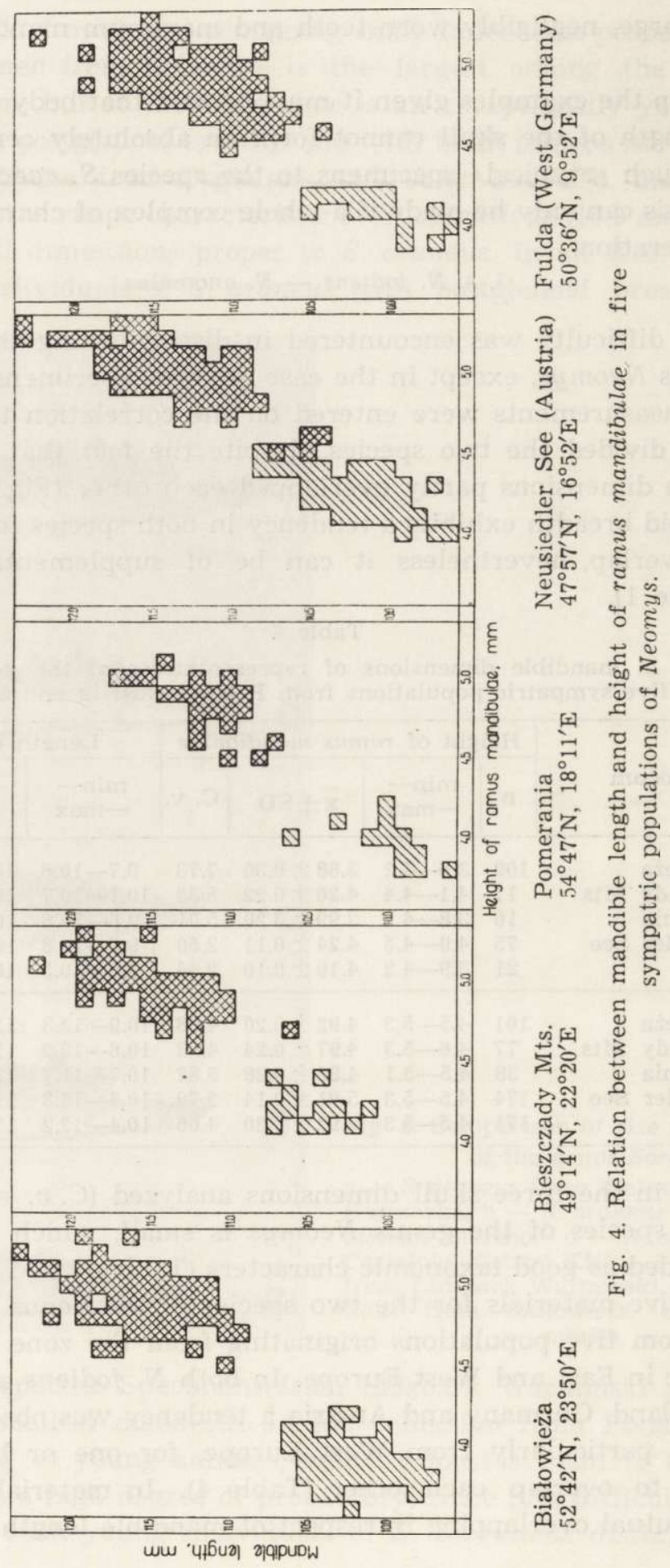


in the population from Bieszczady Mountains (Cisna, district Lesko) out of the three examined (two remaining populations - Krokowa, district Puck - Pomerania and Białowieża, district Hajnówka - Białowieża Primeval Forest). In material from West Germany (Fulda) and Austria (Neusiedler See), on the other hand, values of two mandible dimensions were found mutually to overlap (Table 4).

Complete separation of the two species was, however, obtained on the correlation table, both for Polish and West European specimens, when ranges of variations in mandible dimensions were individually considered within each sympatric population separately (Fig. 4).

Three mandibles of Neomys were found, for which the species was not known, and which differed considerably in their lenghts from typical dimensions for $N$. fodiens. On the correlation table they came in between the two species. Calculation of the index after B ü h l e r (1964), contained within limits 18.34-18.78, and detailed comparison with mandibles of both species justified the conclusion that they belong to $N$. fodiens.

$$
\text { 3. 5. C. russula }- \text { C. leucodon }
$$

Skulls of two species of Crocidura cannot be distinguished on the basis of absolute values of the measurements used (Table 1). Even when the two measurements of the mandible were entered on the distinguishing diagram (Fig. 5) completely reliable results could not be obtained. The range common to both species falls in mandible length classes 9.6-10.8 $\mathrm{mm}$ and of height of ramus mandibulae $4.3-5.1 \mathrm{~mm}$, containing $31.42 \%$ of the specimens of C. russula and $10.48 \%$ of C. leucodon.

\section{6. C. leucodon - C. suaveolens}

Complete separation of these two species on the basis of absolute values of the measurements used, treated individually, is limited (Table 1), but postglenoid breadth may be of supplementary significance here (Table 1).

Complete separation of the two species could not be obtained even by using the correlation table (Fig. 5). The range in common, however, falls only on the following classes: mandible length $9.4 \mathrm{~mm}$ and height of ramus mandibulae $4.2-4.3 \mathrm{~mm}$, covering $1.02 \%$ of the specimens of $C$. leucodon and $6.53 \%$ of $C$. suaveolens.

The fact merits emphasis that low values of mandible dimensions, as in the case of $S$. araneus, were observed only in very young representatives of C. leucodon (minimal wear of teeth) and that it seems likely that it is in fact their immaturity and consequently incomplete growth of the Acta theriol. 23 
skull which might have contributed to the degree of overlapping of their dimension values which was found in the range of $C$. suaveolens.

The variation in the dimensions of the rostral part of the skull found

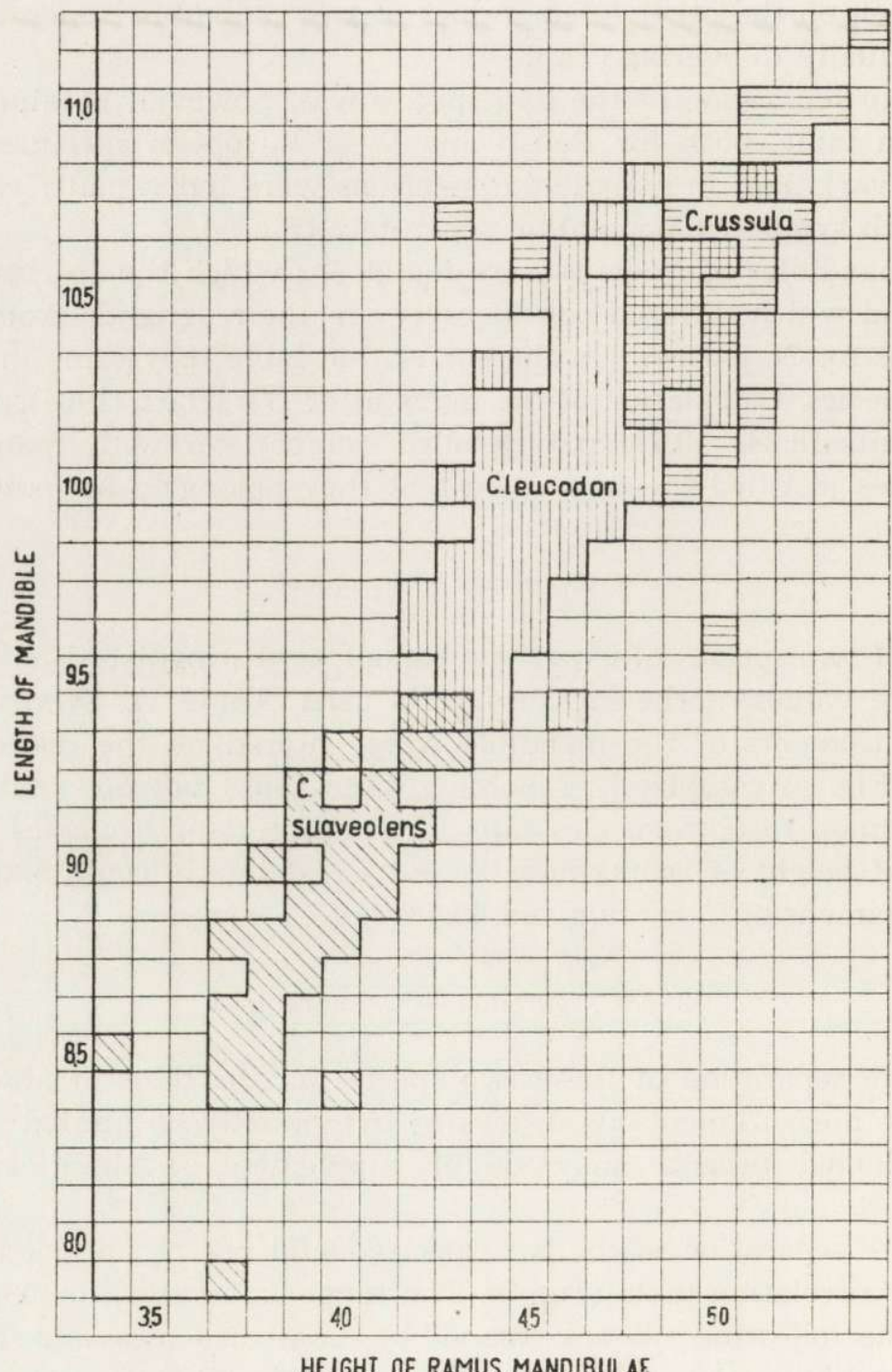

Fig. 5. Relation between mandible length and height of ramus mandibulae in representatives of the genus Crocidura.

in representatives of the genus Crocidura is also small in comparison witl species belonging to the other genera examined (Table 1). 


\section{DISCUSSION}

In the case of the three lowland species of shrews of the genus Sorex and representatives of the genus Neomys, the measurements made of the rostral part of the skull possess full taxonomic value (Table 1, Fig. 2 and 4) and fully confirms the usefulness of the earlier data given by $\mathrm{B} \mathrm{u}$ chalczyk \& Raczyński (1961).

Analysis made to distinguish S. alpinus, on the basis of both the mandibular index and two mandible dimensions, gives a satisfactory result. This is of real practical importance, particularly as the double-peaked crown of tooth $\mathrm{I}_{2}$ is not an adequate character for this purpose, since the crown becomes worn with age and these teeth might be missing in fossil material or material obtained from owl pellets. In addition, transitory irregular wear of the crown of $\mathrm{I}_{2}$, similar to the relations found in $\mathrm{S}$. alpinus, may occur in some representatives of $S$. araneus (D e h n e l, 1949).

The ranges of mandibular length mutually overlapped (1 specimen) in the sympatric populations of the two species of Neomys from Bieszczady Mountains and Fulda, while overlapping in both measurements of the mandible was observed in material from Neusiedler See (Fig. 4, Table 4). The latter case applied to the four specimens identified by Dr. H. P i ep e r as $N$. fodiens.

No mutual overlapping was observed in the height of ramus mandibulae in specimens obtained from three Polish populations, and from similar material from Hungary and Rumania (Schmidt, 1969; H a$\mathrm{m}$ a r \& K ova c s, 1964) and Fulda (West Germany). However, the West European species of this genus (B ühler, 1964; M e yla n, 1967), frequently exhibit a considerable degree of mutual overlapping in values of the height of ramus mandibulae. It is thus only possible completely to distinguish between these species in western Europe by using a discrimination analysis (cf. B ühler, 1964; R e mpe \& B ühler, 1969). It was found, however, that this is not always essential, since relatively often it is possible to distinguish the two species of the genus Neomys solely on the basis of the height of ramus mandibulae. In addition, application of a correlation diagram to these populations in which mutual overlapping of different measurements of the mandible was found to occur permits complete distinction to be made between the two species (cf. Fig. 4).

Some authors have drawn attention to differences in dimensions between different populations of the two species of Neomys. For instance $\mathrm{P}$ i e per (1966) states that the height of ramus mandibulae in Europe in $N$. anomalus decreases from west to north-east and that $N$. fodiens exhibits the reverse trend. M eylan (1967) showed that $N$. anomalus 
from Switzerland are larger than individuals of this species from Białowieża (cf. also $\mathrm{Krat}$ ochvil, 1954). These authors encountered difficulty on account of these differences in distinguishing between the two species in West Europe. It would, however, be difficult to descry a clearly directional trend in variations here, when it is remembered that differences in the height of ramus mandibulae in $N$. anomalus from Białowieża are significantly different from both the eastern population from the Bieszczady Mountains, and also from the West European (Neusiedler See, Fulda) by $(0.01>\mathrm{P}<0.05$ and $0.01>\mathrm{P}<0.05)$ respectively. The situation is similar in the reciprocal differentiation of dimensions in $N$. fodiens between different populations. It would also seem that these differences are shown synchronously, in the same degree in both species of Neomys.

It would appear that the facts found are primarily an expression of interpopulation differences. They undoubtedly depend to some extent on losal conditions under which the given population of water shrews lives. It would be possible finally to interpret the significance of these differences, only if special studies were carried out.

The usefulness of the three dimensions of the rostral part of the skull in representatives of the genus Crocidura is relatively slight in relation to the pair of species - C. leucodon and C. russula, but far greater in the case of $C$. leucodon and $C$. suaveolens. In order to identify skulls of the genus Crocidura more exactly it would therefore be necessary as a basis to take the whole complex of measurements and descriptive characters given by $\mathrm{R}$ i chter (1963 and 1964), and also the data given by $\mathrm{Schmidt}$ (1967), and $\mathrm{Hamar} \& \mathrm{Simionescu}$ (1967). Odontological characters have been shown to be completely unreliable in the light of data given by B u chalc z y k (1958), R i c h t er (1963) and H umiński \& Wójcik-Migała (1967).

Analysis of comparative materials allowed the author to draw attention to representatives of $S$. araneus and $N$. fodiens distinguished by minimum dimensions of the skull. Cases of specimens with small body and skull measurements in S. araneus are not rare (cf. K u bi k, 1951; S c h ub a r th, 1958), but these authors define them by the term »dwarf « and base their assumption on fully documented representatives. In the present study attention was originally paid to them only on account of their minimum dimensions of the mandible.

It is difficult to assess the origin of the dwarf specimens of $S$. araneus and at present goes no further than hypothesis. K u bi k (1951) assumes that these animals are shrews orphaned early on by their mothers, immediately after leaving the nest, and in consequence they bear lasting traces of starvation. The author's assumption is also likely, that owls 
might have caught the shrews while still young and not fully grown, and that they were later found in the pellets. Such specimens may undoubtedly occur more often in owls' prey than in collections of $S$. araneus obtained by trapping. For instance a 13-day old specimen of $S$. araneus from captivity had a mandible length of $8.6 \mathrm{~mm}$, and height of ramus mandibulae $-3.6 \mathrm{~mm}$, and therefore it came within the ranges characteristic of $S$. caecutiens. This example, and also data from table 3, confirm the author's original assumption that minimum dimensions of the mandible in $S$. araneus may be primarily accounted for by the given individual having failed to complete postnatal development.

Acknowledgements: The author is indebted to Dr. H. P i e per for providing measurements of representatives of the genus Neomys used in this study. His thanks are also due to Dr. Z. P u cek for critical reading of the first draft of the manuscript and for his helpful suggestions during the course of the work.

\section{REFERENCES}

1. B u cha lc z y k T., 1958: Die Feldspitzmaus - Crocidura leucodon (H e r m a n n) in den nordöstlichen Gebieten Polens. Acta theriol., 2, 3: 55-70.

2. Buchalczyk T. \& R a c zyński J., 1961: Taksonomiczna wartość niektórych pomiarów czaszki krajowych przedstawicieli rodzaju Sorex Linnae us, 1758 i Neomys $\mathrm{K}$ a u p, 1829. Acta theriol., 5, 9: 115-124.

3. B ühle r P., 1964: Zur Gattungs- und Artbestimmung von Neomys-Schädeln. Gleichzeitig eine Einführung in die Methodik der optimalen Trennung zweier systematischer Einheiten mit Hilfe mehrerer Merkmale. Ztschr. Säugetierkde, 29, 2: $65-93$.

4. Dehnel A., 1949: Badania nad rodzajem Sorex L. Annls Univ. M. Curie-Skłodowska, C, 4, 2: 17-74.

5. H a m a r M. \& Kovacs A., 1964: Neue Daten über die Gattung Neomys K a u p (1829) in der Rumänischen Volksrepublik. Acta theriol., 9, 20: 377-380.

6. Hamar M. \& Simionescu V., 1967: Date noi privind variabilitatea si raspindirea geografica a genuli Crocidura Wagle r (1832) (Insectivora) in Republica Socialista Romania. Comunicari de zool., 5: 115-125.

7. H umiński S. \& Wójcik-Migała I., 1967: Note on Crocidura suaveolens (Pa 11 a s, 1811) from Poland. Acta theriol., 12, 12: 168-171.

8. Kratochvíl J., 1954: Přispěvek $\mathrm{k}$ řešeni přislušnosti našich populaci rejske černého (Neomys anomalus). Zool. ent. Listy, 3, 3: 167-168.

9. Kubik J., 1951: Analiza puławskiej populacji Sorex araneus araneus L. i Sorex minutus minutus L. Annls Univ. M. Curie-Skłodowska, C, 5, 11: 335-372.

10. Me y lan A., 1967: Les petits mammiferes terrestres du Valais Central (Suisse). Mammalia, 31, 2: 225-245.

11. Pieper H., 1966: Úber die Artbestimmung von Neomys-Mandibeln mit Hilfe der Fisherschen Diskriminanz-Analyse. Ztschr: Säugetierkde, 31, 5: 402-403.

12. Raczyński J., 1961: Convenient taxonomic features of skulls of certain mammals from owl pellets. Acta theriol., 5, 20: 295-297.

13. R e mpe U. \& Bühler P., 1969: Zum Einfluss der geographischen und altersbedingten Variabilität bei der Bestimmung von Neomys-Mandibeln mit Hilfe der Diskriminanzanalyse. Ztschr. Säugetierkde, 34, 3: 148-164. 
14. Richter H., 1963: Zur Unterscheidung von Crocidura r. russula und Croci. dura l. leucodon nach Schädelmerkmalen, Gebiss und Hüftknochen. Zool. Abh. Ber. Mus. Tierk. Dresden, 26, 7: 123-133.

15. R i chter H., 1964: Bestimmung der Unterkiefer (Mandibulae) von Crocidura $r$. russula (H e rmann, 1780) und Crocidura l. leucodon (Hermann, 1780). Ztschr. Säugetierkde, 29, 4: 253.

16. Ruprecht A. L., 1969: Taxonomic value of mandible measurements in the genus Plecotus G e of froy, 1818. Acta theriol., 14, 6: 63-68.

17. S chmidt E., 1967: Vergleichende und populationsstatistische Untersuchungen an Unterkiefern der Feld- und Gartenspitzmaus, Crocidura leucodon (H e r$\mathrm{m}$ a n n, 1780) und Crocidura suaveolens (P a lla s, 1811), in Ungarn. Säugetierkdl. Mitt., 15, 1: 61-67.

18. Schmidt E., 1969: Úber die Koronoidhöhe als Trennungsmerkmal bei den Neomys-Arten in Mitteleuropa sowie über neue Neomys-Fundorte in Ungarn. Säugetierkdl. Mitt., 17, 2: 132-136.

19. Schubarth H., 1958: Zur Variabilität von Sorex araneus araneus L. Acta theriol., 2, 9: 175-202.

Accepted, May 30, 1971.

Mammals Research Institute,

Polish Academy of Sciences,

Białowieża, Poland.

Andrzej L. RUPRECHT

TAKSONOMICZNA WARTOŚ́ POMIARÓW ŻUCHWY U SORICIDAE (INSECTIVORA)

Streszczenie

Zbadano zmienność wymiarów rostralnej części czaszki u 9 gatunków Soricidae z rodzaju Sorex, Neomys oraz Crocidura, pochodzących z obszaru Europy środkowej i zachodniej $(n=3124)$. Materiał był analizowany w parach gatunków, wymiarowo mało zróżnicowanych. Zmienność trzech wymiarów części rostralnej czaszki u badanych gatunków jest niewielka. Długość żuchwy jest zmienna w najmniejszym stọpniu w odróżnieniu od bardziej zmiennych - szerokości postglenoidalnej i wysokości gałęzi żuchwy (Tabela 1). Sorex alpinus jest prawie całkowicie odróżnialny od Sorex araneus na podstawie indeksu mandibularnego (długość żuchwy: wysokość gałęzi żuchwy) - (Ryc. 1, Tabela 2). Pewną trudność w oznaczeniu mogą nastręczać okazy ryjówek wymiarowo zbliżonych do $S$. caecutiens. W takich wypadkach, o ile możliwe, należy opierać się o kompleks cech pomiarowych ciała i czaszki (Ryc. 3, Tabela 3). Szerokość postglenoidalna jest dogodną cechą taksonomiczną dla wyróżniania trzech nizinnych ryjówek z rodzaju Sorex i ma ona znaczenie cechy uzupełniającej przy identyfikacji czaszek z rodzaju Neomys i Crocidura (Tabela 1 i 3). Obydwa wymiary żuchwy, zestawione na diagramie ich korelacji, umożliwiają prawie całkowite oznaczenie większości badanych gatunków (Ryc. 2, 4 i 5). W sto- 
sunkowo najmniejszym stopniu, bo tylko w $68,6 \%$ są odróżnialne żuchwy C. russula i C. leucodon, w oparciu o dwa stosowane wymiary. Bardziej przydatną cechą opisową, pozwalającą na odróżnianie żuchw obu gatunków tych zębiełków, jest według Richter a (1964), zróżnicowanie morfologiczne proc. angularis mandibulae. U obu gatunków rzęsorków obserwowano mniejszą lub większą tendencję do wzajemnego zachodzenia wartości badanych pomiarów w pięciu populacjach. Zastosowanie diagramu korelacji obu wymiarów żuchwy w przypadku pięciu populacji sympatrycznych obu gatunków Neomys, umożliwiło pełne ich rozdzielenie przy indywidualnym rozpatrywaniu każdej populacji (Ryc. 4). Metody te mogą znaleźć praktyczne zastosowanie przy identyfikacji materiałów kopalnych, względnie pochodzących ze zrzutek sów w warunkach Europy środkowej. 